\title{
Pengembangan Instrumen Kematangan Emosi Sebagai Alat Ukur Kesiapan Menjadi Guru Profesional Pada Mahasiswa Prodi PG-PAUD
}

\author{
Eka Oktavianingsih", ${ }^{1, *}$, Siti Fadjryana Fitroh ${ }^{2}$ \\ ${ }^{1,2}$ Universitas Trunojoyo Madura, Indonesia \\ *eka.oktavianingsih@trunojoyo.ac.id
}

\begin{abstract}
Abstrak
Perubahan yang terjadi setiap saat menjadikan tantangan menjadi seorang guru pada jenjang Pendidikan Anak Usia Dini yang profesional semakin hari semakin bertambah. Kematangan emosi diperlukan guru PAUD dalam menghadapi beragam tantangan dan perubahan agar tidak mengalami berbagai masalah seperti stress, kelelahan, kebosanan, dan permasalahan psikologis lainnya. Tujuan dari penelitian ini adalah mengembangkan instrumen yang valid dan reliabel dengan mengukur kematangan emosi sebagai standar alat ukur menilai kesiapan mahasiswa PG-PAUD sebagai guru profesional. Penelitian ini menggunakan metode penelitian dan pengembangan (research and development) dengan mengadaptasi model Borg and Gall. Hasil penelitian menunjukkan bahwa skala kematangan emosi yang dikembangkan telah dinyatakan valid serta reliabel. Skala kematangan emosi tersebut diharapkan dapat mengukur kematangan emosi calon guru sehingga programstudi PG-PAUD kedepannya dapat memberikan intervensi yang sesuai untuk meningkatkan kematangan emosi mahasiswanya. Validitas isi dinilai oleh 3 orang ahli dan didapat melalui indeks Aiken dengan skor minimal 0,8. Reliabilitas skala diperoleh dari uji coba skala terhadap 60 mahasiswa semester 7 yang sudah melakukan PLP II (Pengalaman Lapangan Persekolahan). Hasil reliabilitas menunjukkan bahwa koefisien koefisien Cronbach's Alpha sebesar 0.82 yang berarti memiliki reliabilitas yang tinggi.
\end{abstract}

Kata Kunci: kematangan emosi; kesiapan guru; mahasiswa; profesional

\section{Development of An Emotional Maturity Instrument as A Tool for Measuring Professional Teacher Readiness in Student of Department of Early Chidlhood Education}

\begin{abstract}
Seeing the changes that have occurred makes the challenge of becoming a teacher at the professional Early Childhood Education level increasing day by day. Emotional maturity is needed by ECE teachers in facing various challenges and changes so as not to experience various problems such as stress, fatigue, boredom, and other psychological problems. The purpose of this study was to develop a valid and reliable instrument by measuring emotional maturity as a standard measuring tool for assessing the readiness of PG-PAUD students as professional teachers. This study uses research and development methods by adapting the Borg and Gall model. The results showed that the emotional maturity scale developed was valid and reliable. The scale is expected to measura the emotional maturity of preservice teachehrs so that the ECE study program in the future can provide the appropriate intervention to increase the emotional maturity of its students, The content validity was assessed by 3 experts and obtained through the Aiken index with a minimum score of 0.8. The reliability of the scale is obtained from a scale trial of 607 th semester students who have done PLP II (School Field Experience). Reliability results show that the coefficient of Cronbach's Alpha is 0.82 which means it has high reliability.
\end{abstract}

Keywords: emotional maturity; profesionalism; students; professional. 


\section{PENDAHULUAN}

Berkembangnya ilmu pengetahuan di zaman sekarang khususnya dalam bidang information and communication Technology (ICT) membuat perubahan semakin terasa, termasuk dalam dunia pendidikan. Perubahan tersebut tentunya juga dirasakan oleh guru sehingga menyebabkan tantangan yang dihadapi guru jauh lebih besar (Indrawati, 2020). Kesiapan guru menjadi prioritas yang harus diperhatikan. Seiring dengan keberadaan teknologi dalam segala aspek, maka guru perlu mengembangkan inovasi dan mengkolaborasikan proses belajar dengan teknologi. Selaras dengan momentum cita-cita Indonesia emas 2045 dan penyiapan generasi milenial yang kompeten, maka negara perlu menyiapkan pendidik yang profesional, yaitu pendidik yang mampu memanfaatkan e-learning (Fitriah \& Mirianda, 2019). Selain hal di atas beberapa hal yang harus disiapkan oleh guru mulai dari menghadapi peserta didik yang luar biasa beragam, materi pembelajaran yang lebih komplek, standar proses pembelajaran dan capaian kompetensi akan kemampuan berpikir peserta didik yang lebih tinggi (Pratiwi et al., 2021). Untuk itu dibutuhkan guru yang siap menghadapi tantangan. Terdapat tantangan guru di abad 21 yakni: (1) Teaching in multicultural society; (2) teaching for the construction of meaning; (3) teaching for active learning; (4) teaching and technology; (5) teaching with new view about ability; (6) teaching and choice; (7) teaching and accountability (Husain \& Kaharu, 2020; Sole \& Anggraeni, 2018). Melihat tantangan di atas guru dituntut siap memecahkan masalah sendiri, untuk itu butuh kesiapan psikis dalam diri guru khususnya matang dalam emosi agar kedewasaan penyelesaian masalah dapat di capai.

Dalam beberapa tahun terakhir, pendidikan di Indonesia mulai fokus berorientasi perhatiannya mengarah pada aspek kematangan emosi. Meski terlihat sederhana, ternyata secara realita mengarahkan pendidikan yang bermuara pada aspek kematangan emosi pendidik dan peserta didik tidaklah mudah. Konsep kematangan emosi di kalangan guru menjadi perhatian utama di lembaga pendidikan karena signifikansi dan isu yang berkembang (Kumar \& Kiran, 2017). Hal ini dikarenakan bahwa menjadi guru bukan hal mudah bagi semua orang. Mengajar merupakan pekerjaan rumit dan membuat stress sehingga diperlukan kedewasaan dalam sikap (Prakash, 2013). Mengajar dapat merubah situasi secara emosi apabila mengajar tidak dilakukan secara tepat, maka dapat menimbulkan kecemasan, kemarahan, bahkan depresi bagi guru (Kumar \& Kiran, 2017). Di sisi lain, bahwa profesi guru menjadi salah satu profesi dengan tingkat stress yang paling besar dalam aspek fisik, psikologis dan kepuasan kerja (Leguminosa et al., 2017). Padahal, proses pendidikan yang berhasil memerlukan guru yang 
sukses, efektif, dan kompeten yaitu guru yang dapat menangani perasaan negatifnya secara objektif.

Tidak jauh berbeda dengan hasil penelitian sebelumnya, penelitian yang dilakukan oleh Sveinsdottir, Gunarsdottir, dan Fridriksdottir (Maharani, 2017) melaporkan bahwa lingkungan kerja di sekitar guru memiliki banyak faktor pemicu stres. Banyak sekali faktor pemicu stress yang dialami oleh guru. Kondisi rentan stres tersebut tidak terkecuali juga dimiliki oleh guru pendidikan anak usia dini (PAUD). Menurut Herjany \& Bernarto (2018) yang melakukan penelitian pada guru TK dan SD di sekolah X menyatakan bahwa stress kerja ternyata berdampak pada psikologis dan responsnya bersifat tidak sehat, negatif dan destruktif (merusak) seperti tidur tidak nyenyak, merasa kelelahan dan kebosanan dalam bekerja. Menurut penelitian yang dilakukan Yogisutanti (2019) terhadap guru PAUD di Desa Babakan Kecamatan Ciparay Kabupaten Bandung menunjukkan bahwa sebagian besar penyebab stres sedang adalah adanya konflik peran ganda (menjadi ibu dan wanita karir), beban pekerjaan yang berlebih baik kuantitatif maupun kualitatif, dan tuntutan pengembangan karir. Adawiah \& Romadona (2020) dalam penelitiannya juga menyebutkan faktor penyebab stres yang dialami oleh guru PAUD berupa beban kerja, tuntutan orangtua siswa, latar belakang pendidikan, lingkungan kerja, peran ganda, manajemen waktu, dan manajemen diri. Pada kenyataannya, beban dan tanggungjawab sebagai guru PAUD memerlukan kesiapan mental yang tinggi, dikarenakan anak usia dini yang dihadapi sangat unik serta membutuhkan penanganan secara individual. Hal ini mengingat bahwa usia dini merupakan masa emas (golden age) sehingga diperlukan stimulasi dan penanganan yang tepat sesuai tahapan usia dalam mempersiapkan mereka baik secara akademik, pengembangan kepribadian, dan kemampuan interpersonal di kemudian hari.

Kematangan emosi merupakan aspek penting dalam keberhasilan kepribadian dari seorang individu. Saat seseorang memiliki tingkat kematangan emosi tinggi maka dia akan dapat menerima baik keadaan dirinya dan orang lain apa adanya, berpikir secara lebih baik dan obyektif, tidak bersifat impulsif, mampu merespon stimulasi dengan cara berpikir baik serta dapat mengatur pikirannya untuk memberikan tanggapan terhadap stimulus yang mengenainya. Orang yang memiliki kematangan emosi yang cukup juga akan mampu mengkontrol emosi dan mengekspresikan emosi secara baik, tidak mudah frustasi dan mampu menghadapi masalah dengan penuh pengertian sehingga meminimalisir dan menghindarkan diri dari kemungkinan mengalami perasaan cemas, tertekan serta ketidaknyamanan emosional yang berujung burnout 
(Hanafi \& Yuniasanti, 2012). Menurut Amiril (2013), guru perlu memiliki kematangan emosi dan meningkatkan kontrol diri yang tinggi agar terhindar dari kemungkinan stress kerja. Berdasarkan temuan di atas, maka dapat dikatakan bahwa saat guru memiliki kematangan emosi maka kemampuan menyesuaikan diri dengan segala macam kondisi yang membuat stress akan dapat teratasi dengan mudah.

Kematangan emosi tidak selalu dapat dikaitkan dengan usia seseorang. Seseorang yang memiliki kematangan emosional berarti orang tersebut sudah dewasa, tetapi orang dewasa belum tentu memiliki kematangan emosional. Seseorang yang mencapai kematangan emosi tentu akan mampu untuk mengendalikan emosionya. Emosi yang dapat dikendalikan akan membuat orang tersebut mampu untuk berpikir secara lebih baik serta dapat menilai dan melihat persoalan dengan lebih obyektif (Walgito, 2004). Oleh sebab itu, kematangan emosi menjadi hal penting dalam kehidupan seseorang.

Seorang guru perlu meningkatkan kematangan emosinya dalam menjalani tugas dan perannya. Saat guru mencapai tahap tersebut, maka akan mampu mengekspresikan segala perilaku secara tepat. Kematangan emosi saat menjadi guru menurut Prakash (2013), terdiri dari: stabilitas emosi, penyesuaian sosial, kemandirian, kasih sayang, dan realistis. Apabila dikaitkan dengan kompetensi wajib yang harus dimiliki guru, yang terdiri dari kompetensi profesional, kompetensi pedagogik, kompetensi kepribadian, dan kompetensi sosial. Kematangan emosi di sini masuk ke dalam kompetensi kepribadian. Menurut Permendikbud Nomor 137 Tahun 2014, kompetensi kepribadian yang harus dimiliki oleh guru antara lain: (a) bertindak sesuai dengan norma, agama, hukum, sosial, dan kebudayaan nasional; (b) menampilkan diri sebagai pribadi yang jujur, berakhlak mulia, dan teladan bagi anak usia dini dan masyarakat; (c) menampilkan diri sebagai pribadi yang mantap, stabil, dewasa, arif, bijaksana, dan berwibawa; (d) menunjukkan etos kerja, tanggungjawab yang tinggi, rasa percaya diri, dan bangga menjadi guru; dan (e) menjunjung tinggi kode etik guru. Masuknya kematangan emosi dalam kompetensi kepribadian membutuhkan banyak pengaruh dari lingkungan agar kematangan tersebut dapat dicapai.. Hal tersebut senada dengan hasil penelitian Hanafi \& Yuniasanti (2012) yang menyatakan bahwa saat individu memiliki kematangan emosi maka akan mampu mengkontrol emosi dan mengekspresikan emosi secara baik, sabar, penuh pengertian serta cukup memiliki toleransi, penuh tanggungjawab, mandiri, tidak mudah frustasi dan menghadapi masalah dengan penuh pengertian. Maka dapat dikatakan 
bahwa memiliki kemampuan tersebut merupakan bagian penting untuk dimiliki oleh guru ataupun calon guru.

Program studi Pendidikan Guru merupakan bagian dari lembaga yang juga memiliki peran sebagai faktor yang dapat mempengaruhi kematangan emosi, dimana lembaga pendidikan memiliki pendidik/dosen yang dapat dijadikan sebagai tokoh berintelektual yang dapat dijadikan sebagai modeling untuk peserta didik/mahasiswa (Hadiati \& Fidrayani, 2019). Lembaga pendidikan tidak hanya memainkan peran penting dalam mengembangkan kemampuan intelektual saja, tetapi juga kematangan emosinya. Lembaga tersebut melatih calon guru dalam semua aspek kematangan emosi melalui berbagai metode. Calon guru dapat memiliki sikap, keterampilan, dan kemampuan menjadi guru yang sukses yaitu melalui pengalaman lapangan berupa interaksi sehari-hari sebagai guru yang dipersiapkan oleh kampus (Sole \& Anggraeni, 2018). Seorang guru yang matang secara sosial menjadi mandiri dalam arti bahwa ia mengembangkan usaha pengarahan diri sendiri dan belajar efisiensi untuk menggunakan waktunya, mengendalikan emosinya, mengembangkan perasaan untuk berurusan dengan orang-orang yang berbeda di masyarakat, mengembangkan hubungan pribadi yang lembut, memperoleh kualitas penyesuaian, kerja sama, pengorbanan, dan kemandirian (Nagra \& Kaur, 2013). Dengan adanya kematangan emosi, maka guru akan mampu untuk membuat penilaian, keputusan dan mengambil tindakan yang tepat ketika dihadapkan dengan masalah dan masalah kritis.

Kematangan emosi merupakan kemampuan seseorang untuk bereaksi dalam bermacam situasi kehidupan dengan cara yang lebih bermanfaat dan terbuka seperti anak-anak (Semiun, 2006). Kematangan emosi juga berkaitan dengan kesiapan seseorang sebagai dampak dari pertumbuhan dan perkembangan (Hurlock, 1980). Seseorang yang memiliki kematangan emosi akan dapat mengontrol diri dengan baik, mengekspresikan emosi dan memberikan reaksi dengan tepat sesuai kondisi yang ada. Menurut Prakash (2013) dimensi dari kematangan emosi antara lain: (1) stabilitas emosi, (2) penyesuaian sosial, (3) kemajuan emosional, (4) kemandirian, (5) kasih sayang, (6) realistis, dan (7) integrasi kepribadian. Stabilitas emosi mencakup kemampuan dalam mengontrol emosi secara baik, sedangkan kasih sayang ditunjukkan dengan sabar dan memiliki toleransi yang baik (Walgito, 2004). Penyesuaian sosial mencakup kemampuan dalam beradaptasi di lingkungan yang baru serta berkomunikasi secara efektif, kemandirian berupa kemampuan dalam menyelesaikan tugas sendiri, dan realistis berarti mampu berpikir realistis serta bersedia menerima kritik dan saran. 
Kematangan emosi pada calon guru perlu diketahui sebelum terjun ke lapangan untuk mengantisipasi timbulnya permasalahan mental calon guru baik ketika masih menjadi mahasiswa maupun ketika sudah menjadi guru. Beberapa penelitian sebelumnya, penelitian oleh Mundia (2010) mencatat kasus seorang calon guru di Brunei yang drop out dari kursus pelatihan karena masalah kesehatan mental yang tidak diobati. Masalah tersebut menghambatnya melakukan pengajaran dengan teman sebaya, pengajaran mikro, dan praktik mengajar di sekolah. Penelitian lain juga menunjukkan bahwa kelelahan fisik,emosi, mental yang dialami guru karena pekerjaan (burnout) secara signifikan dipengaruhi oleh kematangan emosinya (Sukarmi, 2017).

Guru perlu memiliki kematangan emosi yang baik terlebih ketika berurusan dengan siswa dan ketika menciptakan proses belajar-mengajar yang lebih efektif. Tidak hanya penguasaan mata pelajaran, kecerdasan emosi, kepekaan dan kematangan guru merupakan kunci keberhasilan pembelajaran di kelas. Guru yang memiliki kematangan emosi yang baik akan lebih efektif dalam mengajar daripada guru yang tidak matang secara emosi (Yani \& Astuti, 2017). Selain itu, guru yang memiliki kematangan emosi yang baik akan memiliki kemauan untuk menerima pengalaman dan perubahan secara fleksibel (Kaur, 2009). Mereka tidak akan kaku terhadap perubahan maupun inovasi ke arah yang lebih baik. Oleh sebab itu, dengan kematangan emosi guru akan memiliki identitas profesional (Prakash, 2013). Guru yang profesional adalah guru yang benar-benar ahli dalam bidangnya dan mampu melaksanakan tugasnya dengan baik sekaligus memiliki kompetensi dan komitmen yang tinggi dalam menjalankan tugas dan tanggung jawabnya. Diketahui bahwa dalam menjalani itu semua dibutuhkan keahlian dalam kontrol diri tidak dalam hal ini berkaitan dengan kematangan emosional. Menurut Kumar \& Kiran (2017), guru yang memiliki kematangan emosi akan berpotensi memperkuat pengembangan siswanya secara keseluruhan, bahkan dapat menyalurkan bakat tersembunyi mereka. Hal ini menunjukkan bahwa pengaturan dan pengendalian emosi oleh guru menjadi salah satu penentu utama menjadi guru yang efektif.

Berdasarkan permasalahan di atas, maka perlu dikembangkannya instrumen yang dapat mengukur kematangan emosi dari calon guru khususnya guru Pendidikan Anak Usia Dini, sehingga dapat menilai kematangan emosi secara tepat. Hal ini dikarenakan penelitianpenelitian sebelumnya mengembangkan instrumen kematangan emosi secara umum, belum ada untuk guru terlebih calon guru (Ishfaq \& Kamal, 2018; Nuzhat, 2013). Dari hasil penilaian kematangan emosi calon guru dengan skala kematangan emosi yang akan dikembangkan, maka 
programstudi dapat memberikan intervensi secara tepat agar mahasiswa calon guru PAUD ini lebih siap terjun menjadi guru. Penelitian ini bertujuan untuk mengembangkan instrumen kematangan emosi akan kesiapan menjadi guru professional. Penelitian ini melibatkan sebanyak 60 mahasiswa PG-PAUD semester 7 di Universitas Trunojoyo Madura.

\section{METODOLOGI PENELITIAN}

Penelitian ini menggunakan metode penelitian dan pengembangan (Research and Development). Metode penelitian dan pengembangan atau dalam bahasa Inggrisnya Research and Development merupakan metode penelitian yang bertujuan untuk menghasilkan produk tertentu, dan menguji keefektifan produk tersebut (Sugiyono, 2013). Dalam penelitian ini, produk yang akan dikembangkan berupa instrumen pengukuran yaitu skala kematangan emosi calon guru. Adapun tahapan dalam penelitian pengembangan antara lain mencakup: studi pendahuluan dan analisis kebutuhan; pengembangan produk yang mencakup desain produk, validasi produk, dan perbaikan produk; uji coba terbatas; revisi produk; uji coba lapangan utama; revisi produk, uji coba operasional; penyempurnaan produk; serta diseminiasi produk (Wijaya Kuswanto \& Dinda Pratiwi, 2020). Pada penelitian ini, dilakukan modifikasi atau penyesuaian dari tahapan penelitian, sehingga hanya enam dari sepuluh langkah yang dilakukan oleh peneliti. Peneliti melakukan sampai dengan tahapan uji coba lapangan utama. Produk skala kematangan emosi calon guru PAUD yang dihasilkan mengukur beberapa aspek dari kematangan emosi, antara lain: stabilitas emosi, penyesuaian sosial, kemandirian, kasih sayang, dan realistis. Penentuan sampel menggunakan teknik nonprobability sampling jenis quota sampling. Ukuran sampel pada quota sampling cukup besar, yaitu 60 mahasiswa programstudi PG-PAUD Universitas Trunojoyo Madura semester 7 yang sudah melaksanakan PLP (Praktik Lapangan Persekolahan). Penelitian dilakukan selama 1 (satu) bulan.

Pengembangan instrumen skala kematangan emosi calon guru PAUD dalam penelitian ini menggunakan skala Likert. Skala ini biasa digunakan dalam penelitian survei. Terdapat dua bentuk pernyataan dalam aitem skala kematangan emosi juga dibagi menjadi favorable (F) yaitu pernyataan positif dan unfavorable (UF) yaitu pernyataan negatif. Alternatif jawaban atau respon dari setiap pernyataan dalam skala ini mencakup lima antara lain: tidak pernah, jarang, kadang-kadang, sering, dan sangat sering, dimana pertanyaan positif diberi skor 5, 4, 3, 2, dan 1; sedangkan bentuk pertanyaan negatif diberi skor $1,2,3,4$, dan 5 . 
Teknik pengumpulan data yang digunakan yaitu melalui wawancara dan kuesioner. Wawancara dilakukan ketika studi pendahuluan, sedangkan kuesioner digunakan untuk melihat kelayakan (validitas isi) dari skala menurut para ahli. Analisis data dilakukan secara kuantitatif, pertama produk awal divalidasi oleh ahli (di bidang Psikologi) untuk memperoleh instrumen yang valid secara isi. Produk skala kematangan emosi calon guru yang telah dinyatakan valid kemudian diujicobakan kepada calon guru PAUD yaitu mahasiswa PG-PAUD semester 7. Adapun uji reliabilitasnya menggunakan rumus alpha melalui software SPSS 21. Tahap terakhir dilakukan proses penyempurnaan skala kematangan emosi calon guru PAUD agar dapat digunakan secara lebih luas. Adapun langkah-langkah pengembangan instrumen kematangan emosi calon guru dapat dilihat pada gambar 1.

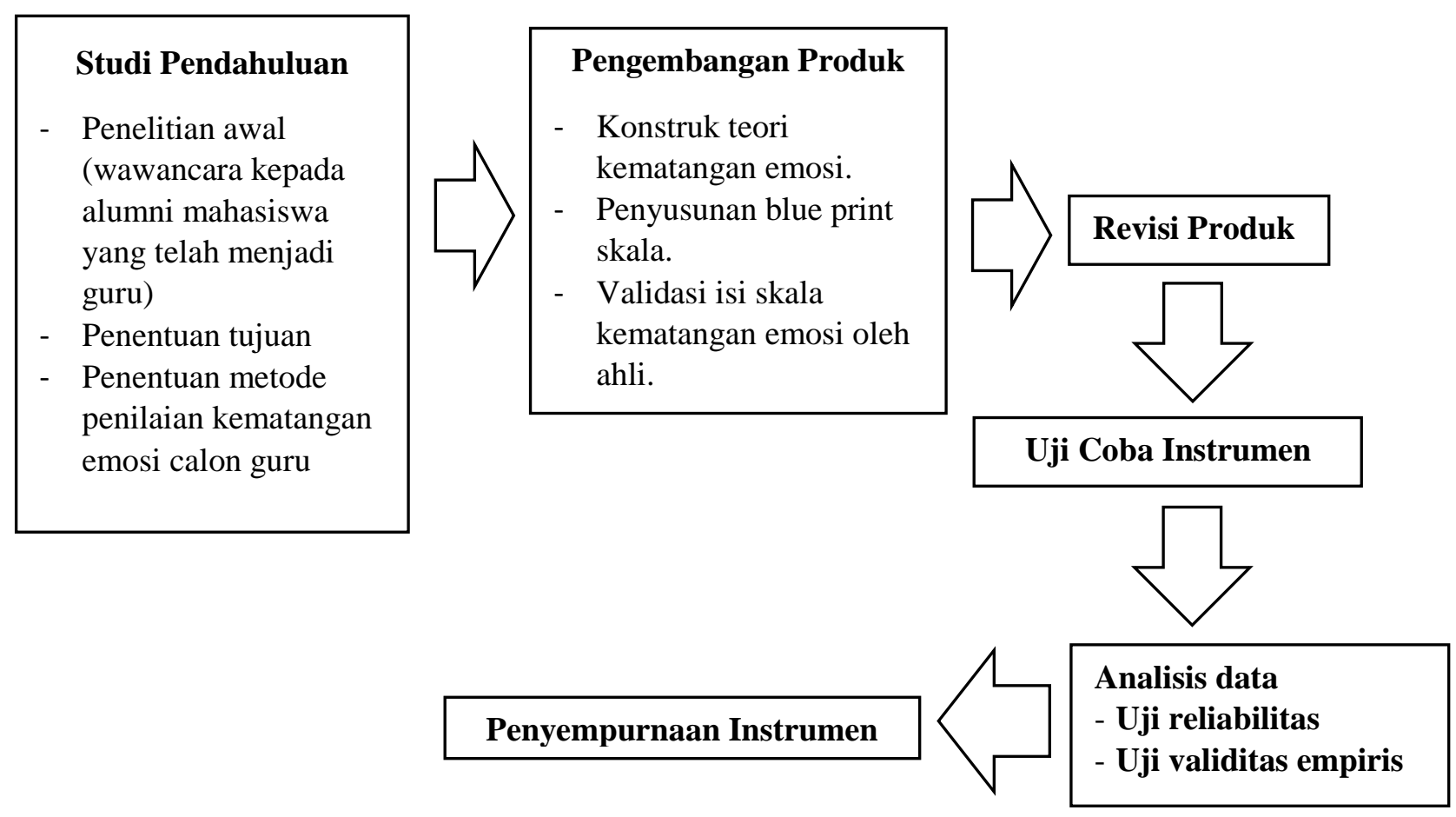

Gambar 1. Desain pengembangan instrumen skala kematangan emosi calon guru (diadaptasi dari model Borg \& Gall)

\section{HASIL PENELITIAN DAN PEMBAHASAN}

\section{A. Hasil}

Penelitian yang dilakukan terhadap mahasiswa Program studi PG-PAUD Universitas Trunojoyo Madura berkaitan dengan instrumen mengukur kesiapan mahasiswa menjadi guru dari aspek kematangan emosi selama ini belum ada. Penilaian kesiapan mahasiswa menjadi guru baru sebatas mengukur kesiapan secara kognitif dan psikomotor. Di sisi lain, penilaian 
pada aspek afektif hanya dinilai dari pengamatan sesaat oleh dosen dan belum menggunakan indikator yang jelas. Padahal penilaian dengan menggunakan indikator yang jelas sesuai dengan konteks mengajar perlu dikembangkan untuk menilai kompetensi calon guru maupun guru serta mengurangi subyektivitas dari penilai (Husain \& Kaharu, 2020).

Dalam pengembangan instrumen pada tahap awal dilakukan dengan wawancara kepada 5 guru PAUD yang merupakan alumni mahasiswa PG-PAUD Universitas Trunojoyo Madura. Wawancara dilakukan dengan tujuan untuk menggali data awal berupa masalah-masalah yang sering mereka hadapi setelah terjun menjadi guru PAUD. Dari data awal tersebut, peneliti kemudian mengidentifikasi masalah-masalah yang masuk ke dalam aspek kematangan emosi guru. Adapun masalah yang sering dihadapi oleh guru PAUD disajikan dalam Tabel 1.

Tabel 1. Masalah yang sering dihadapi Guru PAUD

\begin{tabular}{|c|c|}
\hline Masalah & Uraian \\
\hline Stabilitas Emosi & - Kurang sabar dalam menghadapi anak PAUD. \\
\hline $\begin{array}{l}\text { Penyesuaian } \\
\text { social }\end{array}$ & $\begin{array}{l}\text { - Kesulitan menyesuaikan diri dalam pertemuan organisasi guru } \\
\text { (IGTKI). }\end{array}$ \\
\hline & $\begin{array}{l}\text { - Kesulitan dalam memberikan alasan logis ketika ada orangtua yang } \\
\text { terlalu menuntut. }\end{array}$ \\
\hline Kemandirian & $\begin{array}{l}\text { - Kurang berani dalam berpendapat. } \\
\text { - Kesulitan mengerjakan tugas (perencanaan, pelaksanaan, evaluasi } \\
\text { pembelajaran). }\end{array}$ \\
\hline Kasih saying & $\begin{array}{l}\text { - Kesulitan dalam memahami perbedaan rekan kerja. } \\
\text { - Kesulitan dalam memahami perbedaan antar anak PAUD. }\end{array}$ \\
\hline Realistis & $\begin{array}{l}\text { - Kesulitan dalam menerima masukan dan saran dari guru yang lebih } \\
\text { muda. }\end{array}$ \\
\hline
\end{tabular}

Langkah selanjutnya, peneliti berusaha membangun teori kematangan emosi calon guru atau proses konstruk. Adapun blue print skala kematangan emosi calon guru PAUD ditampilkan dalam Tabel 2. 
Tabel 2. Blue Print Skala Kematangan Emosi Calon Guru PAUD

\begin{tabular}{|c|c|c|c|c|c|}
\hline \multirow{2}{*}{$\begin{array}{l}\text { No. } \\
1\end{array}$} & \multirow{2}{*}{$\begin{array}{l}\text { Aspek } \\
\text { Stabilitas Emosi }\end{array}$} & \multirow{2}{*}{$\begin{array}{l}\text { Indikator } \\
\text { Memahami perasaan }\end{array}$} & \multicolumn{2}{|c|}{ Aitem } & \multirow{2}{*}{$\begin{array}{l}\text { Persentase (\%) } \\
19 \%\end{array}$} \\
\hline & & & $\mathrm{F}$ & 1 & \\
\hline & & sendiri & UF & 2 & \\
\hline & & Mampu mengontrol dan & $\mathrm{F}$ & 3,5 & \\
\hline & & mengarahkan emosi & UF & $4,6,7$ & \\
\hline \multirow[t]{4}{*}{2} & Penyesuaian & Mampu bergaul & $\mathrm{F}$ & 8,11 & $21,5 \%$ \\
\hline & social & lingkungan yang baru & UF & 9,10 & \\
\hline & & Mampu berkomunikasi & $\mathrm{F}$ & 12,14 & \\
\hline & & secara efektif & UF & 13,15 & \\
\hline \multirow[t]{6}{*}{3} & Kemandirian & Mengambil & $\mathrm{F}$ & 16,17 & $19 \%$ \\
\hline & & sendiri & UF & - & \\
\hline & & Melakukan tugas sulit & $\mathrm{F}$ & 19 & \\
\hline & & sendiri & UF & 18,20 & \\
\hline & & Menyelesaikan masalah & $\mathrm{F}$ & 22 & \\
\hline & & sendiri & UF & 21 & \\
\hline \multirow[t]{4}{*}{4} & Kasih sayang & Memahami emosi orang & $\mathrm{F}$ & 25 & $21,5 \%$ \\
\hline & & lain & UF & $23,24,26$ & \\
\hline & & Memahami perbedaan & $\mathrm{F}$ & 27,30 & \\
\hline & & orang lain & UF & 28,29 & \\
\hline \multirow[t]{4}{*}{5} & Realistis & Mampu menyelesaikan & $\mathrm{F}$ & 31,32 & $19 \%$ \\
\hline & & masalah secara obyektif & UF & 33 & \\
\hline & & Mampu menerima kritik & $\mathrm{F}$ & $34,36,37$ & \\
\hline & & dan saran & UF & 35 & \\
\hline
\end{tabular}

Validitas yang digunakan dalam penelitian ini adalah validitas isi yang diperoleh dari skor yang diberikan oleh 3 (tiga) orang ahli yang menekuni bidang psikologi. Validitas isi tersebut kemudian dihitung dengan indeks Aiken sedangkan reliabilitas diperoleh dengan Alpha Cronbach. Apabila indeks Aiken berkisar diantara 0,4-0,8, maka validitas isinya dianggap sedang, jika lebih dari 0,8 dikatakan tinggi (Retnawati, 2016). Pada penelitian ini, jika indeks Aiken kurang dari 0,8 maka aitem akan gugur, sehingga aitem yang sahih adalah aitem yang memiliki indeks lebih dari 0,8 (validitas tinggi). Dari hasil perhitungan validitas, maka 5 aitem 
dinyatakan gugur, dan 32 aitem dinyatakan sahih. Hasil dari perhitungan validitas isi Aiken skala kematangan emosi calon guru disajikan pada Tabel 3.

Tabel 3. Uji Validitas Aiken pada Skala Kematangan Emosi Calon Guru

\begin{tabular}{llccccc}
\hline \multirow{2}{*}{ No } & \multicolumn{1}{c}{ Aspek } & \multicolumn{2}{c}{ Nomor Aitem } & & Nilai V Aiken & Jumlah \\
\cline { 3 - 4 } & & Gugur & Sahih & & & Aitem \\
& & & & Gugur & Sahih & Sahih \\
\hline 1. & Stabilitas Emosi & 2 & $1,3,4,5,6,7$ & 0,5 & $0,83-0,92$ & 6 \\
2. & Penyesuaian & 15 & $8,9,10,11,12,13,14$ & 0,5 & $0,83-1$ & 7 \\
& Sosial & & & & & \\
3. & Kemandirian & - & $16,17,18,19,20,21,22$ & - & $0,83-1$ & 7 \\
4. & Kasih sayang & 23 & $24,25,26,27,28,29,30$ & 0,42 & $0,83-0,92$ & 7 \\
5. & Realistis & 31,32 & $33,34,35,36,37$ & 0,67 & $0,92-1$ & 5 \\
& & & Jumlah & & & 32
\end{tabular}

Langkah selanjutnya, hasil uji coba dari skala kematangan emosi calon guru terhadap 60 mahasiswa calon guru PAUD diperoleh hasil bahwa sebanyak 32 aitem dinyatakan reliabel dengan nilai Reliabilitas Alpha Cronbach sebesar 0.82. Adapun hasil uji reliabilitas skala kematangan emosi calon guru ditunjukkan pada Tabel 4.

Tabel 4. Hasil Reliabilitas berdasarkan Alpha Cronbach

\begin{tabular}{ll}
\hline Reliabilitas Alpha Cronbach & Keterangan \\
\hline 0.82 & Reliabel \\
\hline
\end{tabular}

\section{B. Pembahasan}

Berdasarkan hasil penelitian, masalah yang dialami oleh guru PAUD dimasukkan ke dalam masalah dalam kompetensi kepribadian. Menurut Hakim (2015), guru yang memilki kompetensi kepribadian seharusnya mandiri dalam bertindak, mematuhi kode etik, bertindak stabil dan mantap sesuai norma. Kompetensi sosial jika dilihat dari beberapa teori, maka masuk kedalam aspek kematangan emosi. Adapun aspek kematangan emosi guru mencakup stabilitas emosi, penyesuaian sosial, kemandirian, kasih sayang dan realistis.

Menurut Prakash (2013), stabilitas emosi merupakan kondisi dimana seseorang dapat bertindak secara tepat (tanpa emosi yang berlebihan) dalam segala situasi. Sebagai guru PAUD, dalam menghadapi anak tentunya akan menemui beragam situasi, sebagai contoh ketika anak susah diajak komunikasi, sulit untuk berkonsentrasi, dan permasalahan yang lainnya. 
Berdasarkan hasil penelitian, guru PAUD sering merasa kurang sabar dalam menghadapi anak usia dini. Hal ini dikarenakan setiap anak memiliki karakteristik yang unik dan berbeda satu sama lain sehingga perlu kesabaran dalam menghadapinya. Keberagaman karakteristik individual anak usia dini membutuhkan penanganan yang khusus dari guru (Puspitarani \& Masykur, 2018).

Kemampuan untuk mengontrol diri membuat seseorang lebih mudah dalam mengkontrol munculnya sebuah konflik, hal tersebut memberikan gambaran bahwa saat seseorang mampu mengendalikan munculnya konflik yang terjadi adalah individu lebih mudah melakukan penyesuaian diri terhadap kondisi lingkungan (Prasetyo et al., 2018). Kematangan emosi dapat membuat individu menyesuaikan diri secara baik meski dalam kondisi stress akibat tekanan ataupun masalah (Fitroh, 2011). Orang yang mencapai kematangan emosi akan berusaha menjaga hubungan sosial dengan lingkungannya (Prakash, 2013). Seorang guru PAUD akan berinteraksi dengan beragam lingkungan sosial mulai dari dengan sesama guru, orangtua, maupun dengan organisasi profesi seperti Himpunan Pendidik dan Tenaga Kependidikan Anak Usia Dini Indonesia(HIMPAUDI) maupun Ikatan Guru Taman Kanak-kanak Indonesia (IGTKI). Berdasarkan hasil wawancara, permasalahan terkait penyesuaian sosial yang dominan dialami oleh guru PAUD adalah kesulitan dalam berinteraksi ketika menghadiri pertemuan organisasi guru TK (IGTKI), terlebih pada guru PAUD yang masih tergolong baru. Selain itu, permasalahan yang lain adalah kesulitan dalam mengkomunikasikan alasan ketika terdapat orangtua yang terlalu menuntut, misalnya menuntut agar anaknya diajarkan lebih banyak calistung (membaca, menulis, dan berhitung).

Kemandirian pada individu yang telah mencapai kematangan emosi ditandai dengan sikap tidak tergantung kepada oranglain, mengambil keputusan sendiri, mengerjakan tugas sesuai dengan kemampuannya, dan memiliki resiliensi diri (Prakash, 2013). Berdasarkan hasil wawancara pada penelitian ini, guru PAUD sering mengalami permasalahan dalam kemandirian seperti kurang berani dalam berpendapat serta merasa kesulitan dalam mengerjakan tugasnya (membuat perencanaan pembelajaran, melakukan pelaksanaan pembelajaran, dan mengevaluasi pembelajaran). Hal ini tentunya sesuai dengan hasil penelitian sebelumnya yang telah dilakukan oleh Febrialismanto (2017) yang menyatakan bahwa sebagian besar guru PAUD di kecamatan Kampar Riau berada dalam kategori rendah dalam hal penguasaan terhadap metode/cara pengembangan bahasa, fisik motorik, sosial emosional serta dalam hal pengolahan materi dan melakukan evaluasi pembelajaran. Hal ini jika dialami oleh 
banyak guru PAUD maka mengakibatkan terhambatnya profesionalisme seorang guru Pendidikan Anak Usia Dini.

Menurut Kinney salah satu seseorang dikatakan memiliki kematangan emosi saat individu memiliki kemampuan menerima sikap dan perilaku orang lain mulai cara berpikir, berperilaku dan mampu menerima perbedaan, sehingga mampu merespon dengan peka keadaan orang lain dan hal ini dapat menunjukkan akan kapasitas untuk keseimbangan secara emosional. Dengan kata lain bahwa calon guru yang memiliki kematangan emosi yang baik akan berusaha memahami perbedaan yang ada pada diri peserta didik maupun pada sesama rekan kerja. Berdasarkan hasil penelitian di atas, terlihat bahwa guru PAUD sering mengalami kesulitan dalam memahami perbedaan yang ada pada anak usia dini. Kasih sayang berupa memahami dan memfasilitasi perbedaan yang dimiliki anak usia dini menjadi poin penting ketika menjadi guru PAUD. Menurut Yusuf (Julia et al., 2019) kajian penelitian tentang kematangan emosi penting untuk dimiliki seorang pengasuh, dimana saat perawatan seorang pengasuh harus dapat melakukan dan memberikan kasih sayang secara penuh serta pendidikan tentang kehidupan agar mempersiapkan anak menjadi pribadi dan anggota masyarakat yang sehat. Hal ini dapat dijadikan sebagai dasar kemampuan yang harus dimiliki calon guru agar mampu memahami perbedaan anak PAUD dalam memberikan pengajaran dan pengasuhan.

Kondisi yang tidak menentu dan perubahan yang ada pada bidang pendidikan tentunya menuntut guru sebagai penggerak pendidikan untuk dapat beradaptasi menyesuaikan diri dalam menerima perubahan yang ada. Terlebih dengan pesatnya kemajuan teknologi informasi, hal ini menuntut guru untuk harus menguasai metodologi dan tren baru sebagai bukti profesionalitas mereka (Mirete et al., 2020). Proses diskusi antar guru juga menjadi sarana belajar untuk menjadikan pengetahuan dan praktik pembelajaran menjadi lebih baik serta menemukan inovasi dalam pembelajaran mereka. Hasil wawancara dalam penelitian ini menunjukkan bahwa guru yang lebih tua cenderung kesulitan dalam menerima masukan dan saran dari guru yang lebih muda dalam hal perbaikan kualitas pembelajaran.

Indikator dalam suatu konstruk psikologis dalam penelitian ini diperoleh dari hasil wawancara pada studi pendahuluan serta diperoleh dari teori dan hasil penelitian yang telah dilakukan sebelumnya. Konstruk teori tersebut didapatkan pada setiap sikap kemudian dikembangkan menjadi indikator yang selanjutnya disusun menjadi beberapa aitem. Selain itu, untuk mengetahui apakah skala mampu menghasilkan data yang akurat sesuai dengan tujuan ukurnya, maka diperlukan suatu proses pengujian validitas atau validasi (Syaifuddin, 2012). 
Validasi yang telah dilakukan telah sesuai dengan menggunakan indeks Aiken sehingga diperoleh 32 pernyataan yang sahih.

Produk akhir berupa skala kematangan emosi calon guru telah dapat digunakan secara lebih luas dikarenakan telah memenuhi kriteria pengembangan instrumen. Hal ini selaras dengan pendapat Sugiyono yang menyatakan bahwa keefektifan instrumen dapat dilihat apabila memenuhi kriteria valid, reliabel, obyektif, sistematis, ekonomis, dan praktis (Sugiyono, 2018). Dari hasil pengembangan skala yang telah dilakukan oleh peneliti, maka skala kematangan emosi pada mahasiswa prodi PG-PAUD sebagai calon guru profesional memenuhi kriteria valid dan reliabel.

\section{SIMPULAN DAN SARAN}

Berdasarkan hasil penelitian dan pembahasan sebelumnya, maka kemudian dapat ditarik kesimpulan sebagai berikut. Programstudi PG-PAUD Universitas Trunojoyo Madura selama ini belum pernah menggunakan skala kematangan emosi untuk mengukur kesiapan mahasiswa menjadi guru PAUD yang profesional. Selanjutnya, berdasarkan studi awal, permasalahanpermasalahan yang sering dialami guru PAUD berkaitan dengan kematangan emosi antara lain: (a) kurang sabar dalam menghadapi anak PAUD, (b) kesulitan menyesuaikan diri dalam pertemuan organisasi guru seperti Himpunan Pendidik dan Tenaga Kependidikan Anak Usia Dini Indonesia (HIMPAUDI) maupun Ikatan Guru Taman Kanak-kanak Indonesia (IGTKI), (c) kesulitan dalam memberikan alasan logis ketika ada orangtua yang terlalu menuntut, (d) kurang berani dalam berpendapat, (e) kesulitan mengerjakan tugas (perencanaan pembelajaran, pelaksanaan pembelajaran, evaluasi pembelajaran), (f) kesulitan memahami perbedaan rekan kerja, (g) kesulitan memahami perbedaan pada anak usia dini, dan (h) kesulitan menerima masukan dan saran dari guru yang lebih muda.

Pengembangan skala kematangan emosi calon guru yang dilakukan menghasilkan instrumen skala kematangan emosi calon guru yang valid. Adapun aspek-aspek kematangan emosi pada guru mencakup: stabilitas emosi, penyesuaian sosial, kemandirian, kasih sayang, dan realistis. Validitas isi diketahui berdasarkan penilaian tiga (3) ahli di bidang Psikologi dengan perhitungan indeks Aiken $>0.8$ (validitas tinggi) dan menghasilkan sebanyak 32 aitem yang sahih. Hasil ujicoba skala kematangan emosi terhadap 60 mahasiswa PG-PAUD semester 7 kemudian diukur reliabilitasnya menggunakan rumus Alpha Cronbach dengan nilai 0.82 yang berarti bahwa instrumen memiliki derajat reliabilitas yang tinggi. 


\section{UCAPAN TERIMAKSIH}

Ucapan terimakasih diucapkan kepada Programstudi PG-PAUD Universitas Trunojoyo Madura yang telah memberikan izin penelitian ini. Kami juga mengucapkan terimakasih kepada responden mahasiswa PG-PAUD Universitas Trunojoyo Madura serta tim validator yang telah terlibat dalam penelitian ini. Semoga selanjutnya artikel penelitian ini dapat memberikan manfaat lebih luas.

\section{DAFTAR PUSTAKA}

Adawiah, L. R., \& Romadona, N. (2020). Why are Teachers Vulnerable to Stress ? Advances in Social Science, Education and Humanities Research, 538, 283-286.

Amiril, F. A. R. (2013). Hubungan antara kematangan emosi dan kontrol diri dengan stress kerja pada guru SLB di Kota Malang. Universitas Negeri Malang.

Febrialismanto. (2017). Analisis kompetensi profesional guru PG PAUD Kabupaten Kampar Provinsi Riau. Jurnal Pendidikan Anak, 6(2), 121-136.

Fitriah, D., \& Mirianda, M. U. (2019). Kesiapan guru dalam menghadapi tantangan pendidikan berbasis teknologi. Prosiding Seminar Nasional Program Pascasarjana Universitas Pgri Palembang.

Fitroh, S. F. (2011). Hubungan antara kematangan emosi dan hardiness dengan penyesuaian diri menantu perempuan yang tinggal di rumah ibu mertua. Psikoislamika: Jurnal Psikologi Dan Psikologi Islam, 8(1).

Hadiati, E., \& Fidrayani, F. (2019). Manajemen Pembelajaran Pendidikan Anak Usia Dini. AlAthfaal: Jurnal Ilmiah Pendidikan Anak Usia Dini, 2(1), 69-78. https://doi.org/10.24042/ajipaud.v2i1.4818

Hakim, A. (2015). Contribution of competence teacher (pedagogical, personality, professional competence and social) on the performance of learning. The International Journal of Engineering and Science, 4(2), 1-12.

Hanafi, M., \& Yuniasanti, R. (2012). Hubungan antara kematangan emosi dan burnout pada perawat Rumah Sakit PKU Muhammadiyah Bantul Yogyakarta. Insight, 10(1), 65-76.

Herjany, E., \& Bernarto, I. (2018). Pengaruh lingkungan kerja, kepuasan kerja, dan stress kerja terhadap komitmen organisasi guru tk dan sd pada sekolah x di Jakarta Barat. Jurnal Manajemen Indonesia, 18(2), 154-164.

Hurlock, E. B. (1980). Psikologi perkembangan. Jakarta: Erlangga.

Husain, R., \& Kaharu, A. (2020). Menghadapi Era Abad 21: Tantangan Guru Pendidikan Anak Usia Dini di Kabupaten Bone Bolango. Jurnal Obsesi : Jurnal Pendidikan Anak Usia Dini, 5(1), 85. https://doi.org/10.31004/obsesi.v5i1.527

Indrawati, T. (2020). Efektivitas Program Positif Parenting Dalam Mengurangi Stres Pengasuhan Pada Ibu Muda. 3(2), 201-215.

Ishfaq, N., \& Kamal, A. (2018). Translation and Validation of Emotional Maturity Scale on Juvenile Delinquents, Pakistan. Psycho-Lingua, 48(2), 140-148.

Julia, H., Jarnawi, J., \& Indra, S. (2019). Pola Pengasuhan Pada Konteks Kematangan Emosional Ibu Single Parent. Indonesian Journal of Counseling and Development, 1(1), $31-49$. 
Kaur, B. (2009). Study of mental health of student teachers in relation to intelligence values and attitude towards teaching profession. Chandigarh.

Kumar, R. A., \& Kiran. (2017). Emotional maturity :A study of secondary school teachers. Educational Question: An International Journal of Education and Applied Social Science, 8(2), 547-552. https://doi.org/10.5958/2230-7311.2017.00102.7

Leguminosa, P., Nashori, F., \& Rachmawati, M. A. (2017). Untuk Menurunkan Stres Kerja Guru Di Sekolah Inklusi. Jurnal Ilmiah Psikologi Terapan, 5(2), 186.

Maharani, E. A. (2017). Analisis komparatif faktor penyebab dan tingkat stres guru PAUD selama menjalani tugas belajar strata-1 (S1). Proceedings International Conference on Indonesian Islam, Education and Science, 437.

Mirete, A. B., Maquilón, J. J., Mirete, L., \& Rodríguez, R. A. (2020). Digital competence and university teachers' conceptions about teaching. A structural causal model. Sustainability $\backslash, 12(12)$. https://doi.org/10.3390/SU12124842

Mundia, L. (2010). The status of a trainee teacher with mental-health problems: Dilemmas on inclusion and exclusion in higher education. Global Journal of Health Science, 2(2), 172.

Nagra, V., \& Kaur, M. (2013). Social maturity among student teachers. Journal of Education and Psychological Research, 2(1), 10-16.

Nuzhat, J. (2013). Emotional Maturity of Male and Female Kashmir University of India Distance Learners-A Comparative Study. Journal of Culture, Society and DevelopmentAn Open Access International Journal, 2(1999), 24-28.

Prakash, C. P. (2013). Emotional maturity and teaching effectiveness. Samwaad: E- Journal, 2(2), 44-47.

Prasetyo, A. Y., Fathoni, A., \& Malik, D. (2018). Analisis pengaruh konflik keluargapekerjaan, hardiness, self efficacy terhadap stress kerja dengan dukungan sosial sebagai variabel moderasinya (studi pada guru Demak) Adi. Journal of Management, 4(4), 1-25.

Pratiwi, D. D., Mujib, Andriani, S., Mardiyah, Kuswanto, C. W., \& Utami, E. (2021). Application of algebraic tile media with gasing: Ability to understand mathematical concepts and student creativity. IOP Conference Series: Earth and Environmental Science, 1796(1). https://doi.org/10.1088/1742-6596/1796/1/012023

Puspitarani, P., \& Masykur, A. M. (2018). Makna menjadi guru Taman Kanak-kanak (Sebuah studi kualitatif fenomenologis). Jurnal Empati, 7(1), 308-313.

Retnawati, H. (2016). Analisis kuantitatif instrumen penelitian. Yogyakarta: Parama Publishing.

Sole, F. B., \& Anggraeni, D. M. (2018). Inovasi Pembelajaran Elektronik dan Tantangan Guru Abad 21. Jurnal Penelitian Dan Pengkajian Ilmu Pendidikan: E-Saintika, 2(1), 10. https://doi.org/10.36312/e-saintika.v2i1.79

Sugiyono. (2013). Metode Penelitian Pendidikan Pendekatan Kuantitatif, Kualitatif, dan $R \& D$. Bandung: Alfabeta.

Sugiyono. (2018). Metode Penelitian Pendidikan (Pendekatan Kuantitatif, Kualitatif, dan $R \& D)$. Alfabeta.

Sukarmi. (2017). Pengaruh kematangan emosi dan persepsi beban kerja terhadap burnout (Studi pada guru SLB tunagrahita). In Skripsi. Universitas Muhammadiyah Malang.

Syaifuddin, A. (2012). Penyusunan Skala Psikologi (Kedua). Pustaka Pelajar.

Walgito, B. (2004). Pengantar psikologi umum. Andi Offset.

Wijaya Kuswanto, C., \& Dinda Pratiwi, D. (2020). Pengembangan Bahan Ajar Pendidikan Jasmani untuk Anak Usia Dini Berbasis Tematik. Al-Athfal : Jurnal Pendidikan Anak, 6(1), 55-68. https://doi.org/10.14421/al-athfal.2020.61-05

Yani, W. I. A., \& Astuti, K. (2017). Hubungan Antara Motivasi Berprestasi Dan Kematangan 
Emosi Dengan Kreativitas Pada Guru TK Pembina Purworejo. Insight: Jurnal Ilmiah Psikologi, 17(1), 68. https://doi.org/10.26486/psikologi.v17i1.686

Yogisutanti, G. (2019). Pencegahan Kelelahan Kerja dan Stres Kerja pada Guru Pendidikan Anak Usia Dini ( PAUD ) di Desa Babakan Kecamatan Ciparay Kabupaten Bandung. Jurnal Abdimas BSI, 2(1), 21-31. 